\title{
Antecedents of Customer Switching Intentions: A case study of Nokia Mobile Phones' users
}

\author{
Muhammad Rizwan \\ Lecturer, Department of Management Sciences, \\ The Islamia University of Bahawalpur, Pakistan \\ Email: rizwan.arshad@iub.edu.pk \\ Rashid Hayat \\ MS Scholar, Department of Business Administration \\ NCBA\&E, Bahawalpur, Pakistan \\ Mohsin Ali \\ MS Scholar, Department of Business Administration \\ NCBA\&E, Bahawalpur, Pakistan
}

Accepted: September 13, $2013 \quad$ DOI: 10.5296/jpag.v3i3.6227

\begin{abstract}
The current study moves beyond satisfaction and proposes that switching variables are important factors impacting a customer's decision to switch from a service provider. The purpose of the study analyzes customer switching intention about Nokia mobile. In this sample only one company's customers include, so the findings may not be generalized to other companies. There are many variables which impact on customer decision and enable to customer choose the better services which available in market. These variables impact on customer decision in many ways like, perceived switching cost, the attractiveness of alternatives and service quality. We propose this study to find and support those variables model which influence between core-service satisfaction and customer switching intention. The results indicates that the influence of core-service quality satisfaction on repurchase intentions and decreases switching intention and make customer loyal with that product for a long period. Although switching variables had no influence on repurchase intentions when satisfaction was high, switching variables positively influenced on repurchase intentions when satisfaction was low. Future research in other service industries is called for.
\end{abstract}

Keywords: Customer Switching Intention, Service quality, Nokia Mobile, Price, Substitute 


\section{Introduction}

Customer switching intention in service industries becomes an imperative research issue gradually because of its great influence on service enterprises. Based on inducting the enablers which caused customer switching activities in the existing studies, this research designed a customer switching intention model, switching intention by introducing the variable of customer perceived value into the model. The study indicated that the customer perceived value plays a vital role in the switching intention model as an intermediate variable, most of the controlled incidents by enterprises influence customer switching intention by the adjustment of customer apparent value indirectly. But most of the uncontrolled incidents by enterprises can influence switching intention directly. Meanwhile, core service failure is the key enabler of customer switching intention.

Most previous research on consumers' switching intention has focused on individual variables that have immediate effects on consumers' intentions or behaviors, rather than analyzing it as a multifaceted phenomenon. This article provides that some service provider behaviors swift relationship dissolution, whereas other behaviors create a tendency to switch. This different effect is observed through the mediating effect of customer satisfaction. While poor service quality and low firm loyalty damage consumer satisfaction and have only an indirect effect on switching intentions, price excess and anger incidents have a strong effect on switching, both directly and indirectly through satisfaction. Implications are discussed for customer relationship management. (C) 2007 Wiley Periodicals, Inc

The only 5-10 percent of customers voice their switch to the firm after a service failure its estimates in prior research. A number of studies suggest to ease the complaint expression by tumbling the perceived grumble barriers, e.g. by offering different communication channels. The satisfaction and proposes that switching barriers are key factors impacting a customer's decision to remain with a service provider. Switching barriers make customer difficult or costly and include interpersonal relationships, perceived switching costs, and the magnetism of alternatives. To investigate the causal relationships among promotion effects, switching barriers, and loyalty in the departmental stores. The relationship between switching barriers and loyalty reveals partially the same results as the switching barriers theory of Jones et al. (2000).

Research on service marketing shows that customer retention, not merely customer attainment is critical for service firms (Berry, 1980; Keaveney, 1995). While service quality, relationship quality, and overall service satisfaction are useful in improving customers' intentions to stay with a service firm, what causes customers to switch from one service provider to another remains relatively under studied (Bell, Auh, \& Smalley, 2005; Keaveney, 1995;Parasuraman, Zeithaml, \& Berry, 1988). Understanding customer switching behavior is important because a customer's switching behavior results in the loss of the future revenue stream from that customer. In particular, switching by a service customer is a loss for a firm's high-margin sector of its customer base. The costs associated with acquiring new customers, including account setup, credit checks, and promotional expenses, can be as much as five times the costs of customer retention efforts (Keaveney, 1995; Peters, 1988). Operating costs 
also correlate with the firm's identifying the needs of new customers as well as new customers' becoming familiar with the procedures of the firm.

In a competitive market a firm offers high quality services to the customers to differentiate them. The other variable which is habit and it is the way of action which leads to customer intention to switch off from one product or services to another. And the Goods are available if they serve to the same purposes, are equivalent in functional terms and if they fulfill the same desire and need of the consumers are called substitute. The limited-availability nature of the deal is critical for this strategy to work, and the degree of availability of each item is publicly announced by the seller. On the one hand, a high likelihood of availability for the bargain makes the consumers more attached to the idea of buying. This allows the seller to charge a higher price on the rip-off.

Price is the major role to switch customer intention other side in consumer product and services industry. This negative relationship is credible because when customers switch despite customer satisfaction, switching could result in various potential monetary and non-monetary risks (e.g. a higher price, worse service or higher transaction costs). Time/easiness is another variable which effect to switching intention. Now-a-days customers have no time due to busy life to spend a more intention in shopping so, that they want to easiness \& switching on the buying to get a desired product which is comfortable for them.

\section{Literature review}

\subsection{Customer Switching Intention:}

Research on consumers' switching intention has focused on individual variables that have immediate effects on consumers' intentions or behaviors, rather than analyzing it as a composite phenomenon. This article provides that some service provider behaviors precipitate relationship dissolution, whereas other behaviors create a tendency to switch. An effect of customer satisfaction observed through mediating variables. Low service quality and low firm commitment undermine consumer satisfaction and have only an indirect effect on switching intentions, price unfairness and anger incidents have a strong effect on switching, both directly and indirectly through satisfaction. The only 5-10 percent of customers voice their switch to the firm after a service failure its estimates in prior research. Therefore, the majority of dis-satisfied customers switch the provider. Several studies postulate to ease the complaint voicing by reducing the perceived complaint barriers, e.g. by offering various communication channels. The satisfaction and proposes that switching barriers are important factors impacting a customer's decision to remain with a service provider. Switching barriers make customer difficult or costly and include interpersonal associations, perceived switching costs, and the attractiveness of alternatives. To investigate the causal relationships among promotion effects, switching barriers, and loyalty in the department stores.

\subsection{Service Quality:}

In a competitive market a firm offers high quality services to the customers to differentiate them. 
(Karatepe et al., 2005). Perception of quality with respect to a service is difficult to frame due to

intangibility and heterogeneity associated with the same. Towards interpreting superiority of the service, the perceived service quality has been considered as an attitude (Zeithaml\&Bitner, 2000).

The increasing contribution of service sector to worldwide economy and rigorous competition thereof has constrained researchers to explore the concept of service quality quite often. Over the years, exploration to enhancement of service quality has remained as the focal research object (Yavas et al.,1997, Rust \&Zahorik, 1993; Cronin \& Taylor, 1992, 1994; Buttle, 1996; Crosby \& Stephens, 1987;Parasuraman et.al. 1988; Kearns \& Nadler, 1992; Avkiran, 1994; Julian \&Ramaseshan, 1994; Llosaet.al., 1998). In advance sustainable competitive advantage over competitors through satisfying customer relationships has become one of the strategic weapons for a modern day service firm (Zeithaml et al., 2000). Grönroos (1982) described service quality as a customer's perception of difference between the expected service and the perceived service. The study of service quality was pioneered by PZB, who developed the gaps framework in 1985 and its related SERVQUAL instrument in 1988 (Parasuraman et al., 1985, 1988, 1991). Quite a small number of scholars did agree to the fact that service quality can be represented by a dual-dimension process (Grönroos, 1983;Lehtinen\&Lehtinen, 1982). The first dimension deals with what the service actually delivers and is referred to by PZB (1985) as "outcome quality" and by Grönroos (1984) as "technical quality".

The second dimension deals with how the service is delivered. PZB (1985) described it as "process quality" while Grönroos (1984) termed it as "functional quality". Parasuraman and Zeithaml (2006) defined service quality as "the degree and direction of discrepancy between customers' service perceptions and expectations".

\subsection{Habit:}

Habit is the way of action which leads to customer intention to switch off from one product or services to another.

In the literature that utilizes psychological behavior theory in modal choice research, the theory of planned behavior (TPB,Ajzen, 1985) has been widely used in predicting and explaining intended behavior across a variety of disciplines. The main components of the TPB are a person's own attitudes, subjective norms, perceived behavioral control, intentions, and behavior. More specifically, the TPB is based on the proposition that an individual's behavior is a direct function of behavioral intention and perceived behavioral control. Intentions are themselves shaped by attitudes, subjective norms and perceived behavioral control (Ajzen, 1991). The three determinants of behavioral intentions are each based on an underlying belief structure, behavioral, normative, and control beliefs. In their respective aggregates, behavioral beliefs produce a favorable or unfavorable attitude toward the behavior; normative beliefs result in a perceived social pressure or subjective norm; and control beliefs give rise to perceived behavioral control with regard to performing the 
behavior. Taken together, attitude toward the behavior, subjective norm, and perceived behavioral control translate to the formation of a behavioral intention which is the immediate determinant of actual behavior. The TPB has been used to examine the mode choice behavior in past studies (Bamberg, Ajzen, \& Schmidt, 2003; Bamberg, Rolle, \& Weber, 2003; Bamberg \& Schmidt, 2001, 2003).

From a psychological perspective, travel mode choice may be perceived as not only a deliberate process (i.e. the TPB) but also originating from behavioral habits (Thogersen\& Moller, 2008). Moreover, it has been argued that past behavior is the best predictor of future behavior (Bamberg, Ajzen, et al., 2003; Bamberg, Rolle, et al., 2003).

Unlike the TPB, which assumes that behavior is reasoned, deliberately controlled, and deliberately planned, habit has been perceived as an automatic link between a goal and a specific behavior or as a behavioral script stored in memory (Aarts\&Dijksterhuis, 2000; Aarts, Verplanken, \& van Knippenberg, 1997, 1998; Fujii\&Garling, 2003; Verplanken\&Aarts, 1999). In other words, as habitual behavior demands only a small amount of attention, the individual's control over behavioral intentions well as the behavior itself becomes weak. As long as circumstances remain relatively stable, past mode choice behavior can easily affect latter choice behavior. Therefore, the behavior under consideration is not completely reasoned, and past behavior measured as a proxy for habit plays an important role in predicting future behavior, as supported by previous studies (Bamberg, Ajzen, et al., 2003; Bamberg, Rolle, et al., 2003; Ouellette \& Wood, 1998). The theory of behavior driven by habit has been applied into the mode choice behavior research along with TPB, in works such as Aarts et al. (1998), Bamberg,Ajzen, et al. (2003), Domarchi et al. (2008), Eriksson, Garvill, and Nordlund (2008),

\subsection{Substitute:}

Goods are said to be substitutes if they serve to the same purposes, if they are equivalent in functional terms, if they satisfy the same need.

Retailers frequently use low prices and offer deals to attract consumers. In many cases, these deals apply only to a subset of a stores product line and are often subject to limited availability. Some shops, for example, offer deals that are valid only while supplies last or they might offer price reductions on sale items only to the very first customers of the day. The main result of the paper is that, when two goods have a similar social value, the profit maximizing strategy for the monopolist is to offer a limited-availability deal on one of the goods and then cash in with a high price on the other. Consumers perceive this limited-availability sale as equivalent to a lottery on both which good they will end up with and how much they will pay. The price of the good on sale (the bargain) is chosen such that it is not credible for the consumers to expect not to buy it. Thus, the limited-availability deal works as a bait in luring consumers into the store. Then, because the consumers expect to make a purchase with positive probability and dislike the uncertainty in their consumption outcomes, in the event that the bargain is not available, they prefer to buy the substitute good, even at a higher price (the rip-off ). In other words, consumers go to the store enticed by the possibility of the bargain, but if it is not there they buy a substitute good as a means of 
reducing their disappointment.

We distinguish two cases depending on whether the two items are valued similarly by the consumers. If the goods are closer substitutes, the seller chooses a price of the bargain and a price of the rip-off. That is farther away than consumer's evaluations. If instead the products are distant substitutes, the seller prices them closely or even equally

\subsection{Availability Constraint:}

The limited-availability nature of the deal is critical for this strategy to work, and the degree of

availability of each item is publicly announced by the seller. On the one hand, a high likelihood of availability for the bargain makes the consumers more attached to the idea of buying. This allows the seller to charge a higher price on the rip-off. On the other hand, a greater availability of the bargain necessarily means fewer sales of the rip-off. When choosing the supply level of the bargain item, the seller optimally trades off these two effects, also show that if the bargain is the product with the smaller social surplus, its availability is bounded above by 50\%, implying that less than half of the consumers actually end up buying the item on sale. Hence, under limited availability and loss aversion, dispersion in prices and dispersion in valuations are inversely related. This provides a possible explanation for why relatively similar goods are often offered at different prices. This is somewhat of a bait-and-switch because even if that product is unavailable, you are likely to stay at the store and take advantage of other, less valuable sales. (Denver Better Business Bureau, http://denver.bbb.org)

According to the current FTC regulation, it is not a bait-and-switch if the store communicates upfront that availability is limited. Nevertheless, the popular press and various consumers associations seem to perceive limited-availability deals as being of an exploitative nature, as suggested by the following quotes:

One of the biggest problems during significant sale days like Black Friday is the deceptive Practice of offering a popular, expensive item for a great sale price, but only stocking a very

Limited number of these products. When they are distant substitutes; hence dispersion in prices and dispersion in consumer's evaluations are inversely related. The seller might prefer to offer a deal on the more valuable product, using it as bait, because consumers feel a larger loss, in terms of forgone consumption, if this item is not available and are hence willing to pay a larger premium to reduce the uncertainty in their consumption outcomes. I also show that the bargain item can be a loss leader, that the seller's product line is not welfare-maximizing and that she might supply a socially wasteful product. The results of the model suggest that the current FTC

Guides against Bait Advertising, by allowing retailers to employ limited-availability sales, could

Reduce consumer and social welfare.JEL classification: D11; D42; L11 


\subsection{Price:}

Despite other factor like, availability constraint, need or services Price is the major role to switch customer intention other side in consumer product and services industry.

With reference to the different important aspect of customer Behavior, satisfaction represents a central determinant from Which come different types of influence on other variables and the economic success of a company (e.g. Anderson et al.,1994). Numerous pragmatic studies in the context of goods and services have shown that customer satisfaction has a positive effect on different variables such as customer loyalty(e.g. Biong, 1993; Fornell et al., 1996) and recommendation behavior (e.g. Swan and Oliver, 1989; Mooradian and Oliver, 1997; Selnes and Gronhaug, 1997), but that it has a negative effect on customer switching intention (e.g. Mittal et al.,1998; Hennig-Thurau et al., 2002). This negative relationship is plausible because when customers switch despite customer satisfaction, switching could result in numerous potential monetary and non-monetary risks (e.g. a higher price, worse service or higher transaction costs).

Switching behavior also appears in economic theory, where economic scholars approach switching costs as a mean for keeping customers in relationships (Wieringa and Verhoef, 2007), regardless of their satisfaction with the provider (e.g. Jones et al.,2000; Lee et al., 2001; Burnham et al., 2003; Bansal et al., 2004; Yanamandram andWhite, 2006). More particularly, procedural switching cost enhances calculative commitment, which subsequently increases repurchase intention and decreases undesirable emotions, negative word-of-mouth and ultimately, switching (Jones et al.,2007; Khan et al., 2010). This becomes essential because if customers were able to switch easily, operators would be less inclined to charge excessively high prices or supply poor quality of services (Xavier and Ypsilanti, 2008). Probing further, Burnhamet al. (2003) asserted that switching costs generate passive loyalty, while switching barriers prompt relationship-improving investments (Yen, 2010). Moreover, switching barriers are not only positively affecting the customer retention but also performing an adjustment effect on core service quality and satisfaction on the one hand (Chen and Wang, 2009) and satisfaction and loyalty on the other (Ranaweera and Prabhu, 2003;Kim et al., 2004). Beside relational investments, service recovery and alternative attractiveness, switching costs is also one of the most important categories of switching barriers (Colgate and Lang, 2001).

\subsection{Time/Easiness:}

In current working environment people have so busy and they have no time to spend a more intention in shopping and get a desired product as per specification so they want to easiness and switching online buying which is comfortable.

Today Internet is not only a networking media, but also as transaction medium for consumers at global market in the world, and becomes dominant retailers in the future. The most necessary element of e-retail offers a direct interactive channel as well as no time definition, people and place. To shop on Internet becomes an alternative for consumers since it is more comfortable than conventional shopping which usually attributed with anxious, crowded, 
traffic jam, limited time, parking space and etc. Internet in many countries is still considered as a new medium toll between the retailers and the consumers, and also retaining consumer one-retail is the most issue that is faced any e-retail store. To increase the understanding in this area, the question needs a correct answer. Are consumers ready to embrace Internet shopping? In addition, this study wants to know the reasons, why is the consumer of many countries, particularly in a public institution of higher learning acceptor refuse internet shopping application? And what are dominant predictors that influence the people's intention to shop on internet?

In addition to that Individual may use a technology if they think it is beneficial, convenient and socially important although they do enjoy for using the technology.

\section{MODEL OF CUSTOMER SWITCHING INTENTION}

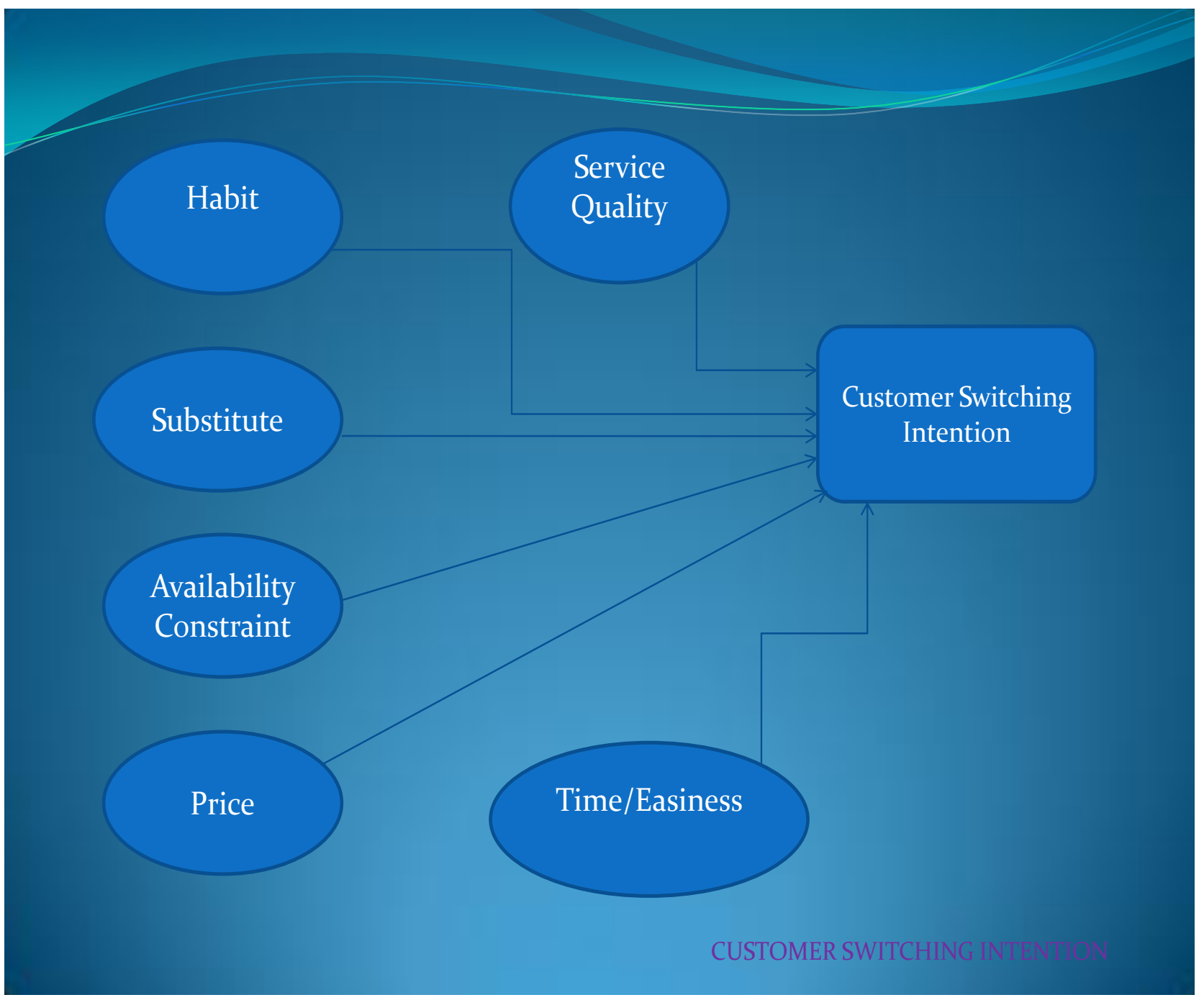




\section{Macrothink}

\section{Hypothesis:}

Based on the ideas outlined above, this study proposes the following hypothesis.

H1: Increases in service quality lead to decrease in customer switching intention.

H2: Increases in habitual lead to increase in switching intention.

H3: Substitute of use has a positive effect on customer switching intention.

H4: Increases in availability constraint decrease the switching intention.

H5: Increases in price lead to increases in switching intention.

H6: Increases in time/easiness decreases the switching intention.

\section{Research Methodology:}

The research methodology which we adopted is descriptive in its nature. Descriptive researches are those researches that describe the existing situation instead of interpreting and making judgments (Creswell, 1994). As this study examines the impact of Independent variables Service Quality, Habit, Substitute, Availability constraint, Price and Time/Easiness on Dependent variable Customer Switching Intention.

\subsection{Sample/Data}

Using convenience method of sampling, 150 self-administered questionnaires were distributed among the students, employees and businessman in Bahawalpur. All questionnaires were returned, so the response rate was $100 \%$.

The current study utilizes a non-probability sampling technique that is convenience sampling. Convenience sampling is a sampling technique that obtains and collects the relevant information from the sample or the unit of the study that are conveniently available (Zikmund, 1997). Convenience sampling is normally used for collecting a large number of completed surveys speedily and with economy (Lym et al., 2010).

Self-Designed questionnaire has been established for data collection. Self-designed questionnaire was divided into two parts; one holding socio-demographic questions and the second part holding questions associated to variables that are Service Quality, Habit, Substitute, Availability constraint, Price, Time/Easiness and Customer Switching Intention.

\subsection{Instruments and Measurement Scales}

The survey instrument encloses two sections. Section 1 includes different personal and demographic variables. This section will attain the respondent's information about gender, age, income, education and status.

Section 2 includes the suppressed variables that are important in the current study. These 


\section{Macrothink}

Journal of Public Administration and Governance

ISSN 2161-7104

2013, Vol. 3, No. 3

variables include Service Quality, Habit, Substitute, Availability constraint, Price, Time/Easiness and Customer Switching Intention.

The scales of the study were adopted from the prior literature and published studies.

\subsection{Procedure}

The questionnaire was circulated among 150 respondents in Bahawalpur. These respondents are selected based on the criteria above stated. Before giving the questionnaire, the purpose of study and questions were explained to the respondents so they can easily fill the questionnaire with related responses. After collecting the completed questionnaires, these questionnaires were implied and arrived into SPSS 17.0 sheet for more analysis.

\subsection{Reliability Analysis}

Overall Cronback's alpha of Customer Switching Intention questionnaire items were 0.644 to 0.755 that is more than acceptable and suggested value 0.50 by Nunnally (1970) and 0.60 by Moss et al. (1998). This shows that all the 23 items were reliable and valid to measure the Customer Switching Intention

\begin{tabular}{|l|l|l|}
\hline scales & Items & Cronback's Alpha \\
\hline Service Quality & 3 & .663 \\
\hline Habit & 3 & .689 \\
\hline Substitute & 3 & .644 \\
\hline Availability Constraint & 4 & .699 \\
\hline Price & 4 & .667 \\
\hline Time/Easiness & 3 & .655 \\
\hline $\begin{array}{l}\text { Customer } \\
\text { Intention }\end{array}$ & 3 & .755 \\
\hline
\end{tabular}




\section{Results and Analysis}

\subsection{Profile of the Respondents}

\begin{tabular}{|c|c|c|c|}
\hline & Category & Frequency & Percentage \\
\hline variables & & & \\
\hline Gender & $\begin{array}{l}\text { Male } \\
\text { Female }\end{array}$ & $\begin{array}{l}67 \\
83\end{array}$ & $\begin{array}{l}44.7 \\
55.3\end{array}$ \\
\hline Age & $\begin{array}{l}\text { 15-20 Years } \\
\text { 20-25 Years } \\
\text { 25-30 Years } \\
\text { 30-35 Years }\end{array}$ & $\begin{array}{l}56 \\
42 \\
37 \\
15\end{array}$ & $\begin{array}{l}37.3 \\
28.0 \\
24.7 \\
10\end{array}$ \\
\hline Income /Rs. & $\begin{array}{l}\text { Below } 15000 \\
15000-25000 \\
25000-35000 \\
35000-45000 \\
45000-55000 \\
\text { Above } 55000\end{array}$ & $\begin{array}{l}54 \\
28 \\
36 \\
22 \\
5 \\
5\end{array}$ & $\begin{array}{l}38.0 \\
18.7 \\
24.0 \\
14.7 \\
3.3 \\
3.3\end{array}$ \\
\hline Education & $\begin{array}{l}\text { Matriculation } \\
\text { Inter } \\
\text { Bachelor } \\
\text { Master } \\
\text { MS/M. Phil } \\
\text { PhD }\end{array}$ & $\begin{array}{l}14 \\
12 \\
50 \\
59 \\
15 \\
0\end{array}$ & $\begin{array}{l}9.3 \\
8.0 \\
33.3 \\
39.33 \\
10.0 \\
0.00\end{array}$ \\
\hline
\end{tabular}




\begin{tabular}{|l|l|l|l|}
\hline Status & Student & 38 & 25.3 \\
Employed & 106 & 70.2 \\
Businessman & 4 & 2.7 \\
Unemployed & 0 & 0.0 \\
Housewife & 2 & 1.3 \\
\hline
\end{tabular}

\subsection{Hypothesis Testing}

\subsubsection{Increases in service quality lead to decrease in customer switching intention}

According to the results of the study, the both variables service quality and customer switching intention has a significant negative relationship with $(\beta=0.410)$ and $(p<0.01)$. That means service quality leads to the customer switching intention more than $40 \%$. Results of the present study confirm the H1.

\subsubsection{Increases in habitual lead to increase in switching intention}

According to the results of the study, the both variables habit and customer switching intention has a significant positive relationship with $(\beta=0.248)$ and $(p<0.01)$. That means habit leads to the customer switching intention almost $25 \%$. Results of the present study confirm the $\mathrm{H} 2$

\subsubsection{Substitute of use has a positive effect on customer switching intention}

According to the results of the study, the both variables substitute and customer switching intention has a significant positive relationship with $(\beta=0.262)$ and $(p<0.01)$. That means substitute leads to the customer switching intention more than $26 \%$. Results of the present study confirm the H3.

\subsubsection{Increases in availability constraint decrease the switching intention}

According to the results of the study, the both variables availability constraint and customer switching intention has a significant negative relationship with $(\beta=0.293)$ and $(p<0.01)$. That means availability constraint leads to the customer switching intention almost $30 \%$. Results of the present study confirm the $\mathrm{H} 4$

\subsubsection{Increases in price lead to increases in switching intention}

According to the results of the study, the both variables service quality and customer switching intention has a significant positive relationship with $(\beta=0.501)$ and $(p<0.01)$. That means price leads to the customer switching intention more than $50 \%$. Results of the present 
study confirm the H5

\subsubsection{Increases in time/easiness decreases the switching intention}

According to the results of the study, the both variables service quality and customer switching intention has a significant positive relationship with $(\beta=0.552)$ and $(p<0.01)$. That means time/easiness leads to the customer switching intention more than $55 \%$. Results of the present study confirm the H6

\section{Regression Results:}

\begin{tabular}{|c|c|c|c|c|c|c|}
\hline Hypothesis & Model variables & Estimate & S.E. & C.R. & $\mathrm{P}$ & Results \\
\hline $\mathrm{H} 1$ & $\begin{array}{l}\mathrm{CSI} \longleftarrow \\
\mathrm{SQ}\end{array}$ & 0.410 & 0.097 & 3.403 & $* * *$ & Supported \\
\hline $\mathrm{H} 2$ & $\begin{array}{l}\mathrm{CSI} \longleftarrow \\
\mathrm{HBT}\end{array}$ & 0.248 & 0.074 & 5.310 & $* * *$ & Supported \\
\hline $\mathrm{H} 3$ & $\begin{array}{l}\text { CSI } \longleftarrow \\
\text { SUB }\end{array}$ & 0.262 & 0.076 & 6.376 & $* * *$ & Supported \\
\hline $\mathrm{H} 4$ & $\begin{array}{l}\mathrm{CSI} \\
\mathrm{AC}\end{array}$ & 0.293 & 0.138 & 3.891 & $* * *$ & Supported \\
\hline H5 & $\begin{array}{l}\text { CSI } \\
\mathrm{P}\end{array}$ & 0.501 & 0.108 & 5.477 & $* * *$ & Supported \\
\hline H6 & $\begin{array}{l}\text { CSI } \\
\text { T/E }\end{array}$ & 0.553 & 0.093 & 5.125 & $* * *$ & Supported \\
\hline
\end{tabular}

\section{Discussion:}

The core objective of the study has been to study the customer switching intention model in the context of a developing country of Pakistan. There is a powerful urge for companies to re-orient their existing marketing strategies towards customer switching intention strategies. The present study has highlighted the importance of switching intention among customers in Pakistan. There is equally strong empirical evidence in the study concerning favorable customer values and beliefs towards the intention.

This paper expands the research of customer switching intention in the area of Mobile 
marketing (Nokia). The basic ground of this study is to reveal the relationship between CSI and their six determinants - service quality, habit, substitute, availability constraint, price, and time/easiness. In this geographical area, it is essential for companies to increase their intention, enhance their Trust, and reduce the switching intention to raise their customer loyalty.

The empirical result demonstrates that CSI has positive relationship with price and substitute which supports all proposed hypotheses. Consequently, it is useful to invest resources to reduce customer switching intention and to enhance the customer loyalty which will ultimately raise customer satisfaction. According to results of this study, service quality and price is the most essential assessor of customer switching intention.

An important finding of this study involves that customer switching intention can reduced through better service quality on competitive prices and offering innovative product feature as per market demand. Strong supply chain is the important factor which make easy availability of demanded product on time which lead to overcome the switching intention. Habit is also create switching intention but the habitual people is very minor portion of market which not affect the product demand on very large scale but organization can capture this portion of market by introducing innovative product by time to time.

\section{Limitations and Future Research}

Moreover these findings, the current study open numerous areas to be discovered in the future research. Convenience samples collected through the self-administrative questionnaire and only for specific product may limit the generalization of the study. this study verifies the hypotheses by means of questionnaire survey which only provides cross-sectional data so that this study cannot observe the dynamic changes of customer switching intention, by service quality, price of product, and availability of substitute through one time survey its required a longitudinal study data. In current study just used Questionnaire method, there is not used of Interview and Observation methods which limit the current study. The current study was cross-sectional in nature and thus cause-and-effect relationships cannot be established definitely.

\section{References:}

[1]Alexandris ,K., Dimitriadis ,N. and Markata ,D.(2002),“Can perceptions of service quality predict Behavior intentions ? An exploratory study in the hotel sector in Greece ", Managing Service Quality, Vol. 12No. 4,pp. 224- 32.

[2]Aydin, S.andOzer, G.(2005), “An analysis of antecedents of customer loyalty in the Turkish Mobile communication market”, European Journal of Marketing, Vol.39Nos7/8,pp.910-23.

[3]Bitner, M.J.and Hubbert, A.R.(1994),“Encounter satisfaction versus overall satisfaction versus quality”, in Rust,R.T.and Oliver,R.L.(Eds), Service Quality: New Directions in Theory and Practice, Sage Publications, London.

[4]Brady, M.K.andCronin,J.J.(2001), “Some new thoughts on conceptualizing and measuring service quality: a hierarchical approach”, Journal of Marketing,Vol.65No.3,pp.34-49. 
[5]Burnham, T. A., Frels, J. K., \& Mahajan, V. (2003). Consumer Switching Costs: A Typology, Antecedents, and Consequences. Journal of the Academy of Marketing Science, 31(2), 109-126. http://dx.doi.org/10.1177\%2F0092070302250897

[6]Chiou, J. S., \& Droge, C. (2006). Service Quality, Trust, Specifi Asset Investment, and Expertise: Direct and Indirect Effects in a Satisfaction-Loyalty Framework. Journal of the Academy of Marketing Science, 34(4), 613-627. http://dx.doi.org/10.1177\%2F0092070306286934

[7]Clemes, M. D., Gan, C. and Kao,T.H.(2007b),“University satisfaction :an empirical analysis", Journal of Marketing for High Education,Vol.17No.2,pp.292-325.

[8] Colgate ,M. and Lang ,B.(2001), "Switching barriers in consumer markets :an investigation of the financial services industry", The Journal of Consumer Marketing,Vol.18Nos4/5, pp.332-48.

[9]Coulter, R. A., Feick, L., \& Price, L. L. (2003). Rethinking the Origins of Involvement and Brand Commitment: Insights from Postsocialist Central Europe. Journal of Consumer Research, 30(2), 151-169. http://dx.doi.org/10.1086\%2F376809

[10]Creswell, J.W. (1994) Research Design: Qualitative \& Quantitative Approaches. London: SAGE Publications

[11]Crosby, L.A. ,Evans ,K.R.,\& Cowles, D.(1990).Relationship quality in services selling: An interpersonal influence perspective. Journal of Marketing, 54(3),68-81

[12]Cui, G., \& Wang, Y. (2010). Consumers' SKU choices in an online supermarket: a latent class approach. Journal of Marketing Management, 26(5-6), 495-514. http://dx.doi.org/10.1080\%2F02672570903534704

[11]Dagger, T. S. ,Sweeney ,J .C.and Johnson, L.W.(2007),“A hierarchical model of service health quality”, Journal of Service Research,Vol.10No.12,pp.123-42.

[13]Deng, Z.,Lu, Y.,Wei ,K .K., \& Zhang, J.(2009).Understanding customer satisfaction And loyalty: An empirical study of mobile instant messages in China. International Journal of Information Management, doi :10.1016/ j.ijinfomgt.2009.10.001

[14]DeRuyter,K.,\& Wetzels , M.G.M.(2000).The impact of perceived listening behavior invoice-to-voice service encounters. Journal of Service Research, 2(3),

[15]Dick ,A.S.,\& Basu,K.(1994).Customer loyalty: Toward an integrated conceptual framework. Journal of the Academy of Marketing Science, 22(2),99-113.

[16]Fornell,C.(1992).A national customer satisfaction barometer :The Swedish experience. Journal of Marketing, 56(1),6-21.

[17]Ganesh J M ,Arnold J, Reynolds K E. Understanding the customer base of service providers: an examination of the differences between switchers and stayers. J Mark 2000 ; 64(3):65-87. 
[18]Garland,R.(2002), "Estimating customer defection in personal retail banking”, International Journal of Bank Marketing,Vol.20 No.7,pp.317-24.

[19]Garland,R.(2002), "Estimating customer defection in personal retail banking”, The International Journal of Bank Marketing,Vol.20No.7,pp.317-25.

[20]Gerpott,T.J.,Rams,W., \& Schindler, A. (2001).Customer retention, loyalty and satisfaction in the German mobile cellular telecommunications market. Telecommunications Policy, 25(4),249-269.

[21]Gronhaug,K. and Gilly, M.C.(1991),“A transaction cost approach to customer dissatisfaction and complaint actions", Journal of Economic Psychology,Vol.12,pp.165-83.

[22] Gronroos,C.(2000), Service Management and Marketing,2nded.,Wiley, Chichester.

[23]Jones M A, Mothers baugh D L,Beatty S E .Switching barriers and repurchase intentions in services. J Retailing2000;76(2):259-74.

[24]Jones,T.O. and Sasser, W.E .Jr (1995),“ Why satisfied customers defect”, Harvard Business Review,Vol.73No.6,pp.88-99.

[25]Kiesler, C.A., 1968. 'Commitment'. In: P.A. Abelson et al. (Eds.), Theories of Cognitive Consistency: A Source Book (pp. 448-455). Chicago, IL: Rand McNally.

[26]Kumar, A. (2005). Explaining consumer acceptance of handheld Internet devices. Journal of Business Research, 58(5), 553-568.

[27]LaBarbera, P. A., \& Mazursky, D. (1983). A Longitudinal Assessment of Consumer Satisfaction/Dissatisfaction: The Dynamic Aspect of the Cognitive Process. Journal of Marketing Research, 20(4), 393-404. http://dx.doi.org/10.2307\%2F3151443

[28]Lee,M.andCunningham,L.F.(2001),“Acost/benefitapproachtounderstandingserviceloyalty ,,TheJournalofServicesMarketing,Vol.15No.2,pp.113-30.

[29]Matthews,C.and Murray,D.(2007),"Helping bank customers switch :a case study", Journal of Financial Services Marketing,Vol.11No.4,pp.360-70

[30]Mavri, M. and Ioannou ,G.(2008), "Customer switching behavior in the Greek banking services using survival analysis”, Managerial Finance,Vol.34No.3,pp.186-97.

[31]Morgan,R.M.and Hunt,S.D.(1994), “The commitment- trust theory of relationship marketing”,Journal of Marketing,Vol.58,July,pp.20-38.

[32]Moss, S., Prosser, H., Costello, H. (1998). Reliability and validity of the PAS-ADD Checklist for detecting psychiatric disorders in adults with intellectual disability. Journal of Intellectual Disability Research. 42, 173-183.

[33]Nunnally, JC. (1970). Introduction to Psychological Measurement. New York: McGraw-Hill.

[34]Oliva TR,OliverL,MacMillanI.A catastrophe model for developing service satisfaction 


\section{Macrothink \\ Journal of Public Administration and Governance \\ ISSN 2161-7104 \\ 2013, Vol. 3, No. 3}

strategies.JMark1992;56(3):83-95.

[35]Oliver,R.L.(1997). Satisfaction: A behavioral perspective on the consumer. Boston: Irwin McGraw-Hill.

[36]Parasuraman , A., Zeithaml, V.A., \& Berry, L.L.(1985).A conceptual model of service quality and its implications for further research. Journal of Marketing, 49(3),41-50.

[37]Parasuraman,A.,Zeithaml,V.A.,\&Berry,L.L.(1988).SERVQUAL:Amultiple-item scale for measuring consumer perceptions of service quality. Journal of Retailing, $64(1), 12-40$.

[38]Reichheld ,F.F.(1996). Theloyaltyeffect.Boston:HarvardBusinessSchoolPress.

[39]Raju, S., Unnava, R. H., \& Votolato Montgomery, N. (2009). The Effect of Brand Commitment on the Evaluation of Nonpreferred Brands: A Disconfirmation Process. Journal of Consumer Research, 35(5), 851-863. http://dx.doi.org/10.1086\%2F592816

[40]Soderlund,M.(1998).Customer satisfaction and its consequences on customer behavior revisited. International Journal of Services Industries Management, 9(2),169-188.

[41]Thompson, D. V., Hamilton, R. W., \& Petrova, P. K. (2009). When Mental Simulation Hinders Behavior: The Effects of Process-Oriented Thinking on Decision Difficulty and Performance.Journal of Consumer Research, 36(4), 562-574. http://dx.doi.org/10.1086\%2F599325

[42]Zeithaml,V.A.,Berry,L. and Parasuraman, A.(1996),"The behavioural consequences of service quality", Journal of Marketing, Vol.60 No. 2,pp.31-46.

[43]Zeithaml,V.A.,\& Bitner,M.J.(2000). Services marketing: Integrating customer focus Across the firm. Madison: McGraw-Hill.

[44] Zikmund, W.R. (1997). Business Research Methods (5th Ed.), Texas: The Dryden Press. 